\title{
Contents, Volume 6 (1995)
}

Andersen, J.: A comparison of pitfall trapping and quadrat sampling of Carabidae (Coleoptera) on river banks ... 65

Atlegrim, O. \& Sjöberg, K.: Effects of clear-cutting and selective felling in Swedish Boreal coniferous forests: response of invertebrate taxa eaten by birds 79

Bagge, P.: Emergence and upstream flight of lotic mayflies and caddisflies (Ephemeroptera and Trichoptera) in a lake outlet, central Finland 91

Bagge, P. \& Hynynen, J.: Plecopteran communities and annual emergence in five forest streams and two outlet streams of central Finland

99

Biström, O.: Uvarus laurentius sp. n. and Africodytes maximus sp. n. and new faunistic records of other Bidessini (Coleoptera, Dytiscidae) from the Ethiopian region .. 43

Eeva, T.: see Veistola, Eeva \& Lehikoinen ................. 177

Ehnström, B., Lăngström, B. \& Hellqvist, C.: Insects in burned forests - forest protection and faunal conservation (preliminary results) 109

Haarto, A.: Five species of flies (Diptera) new to Finland, with notes on additional rare species ........................... 5

Heie, O. E.: The composition of the aphid fauna of Fennoscandia and Denmark .................................. 119

Hellqvist, C.: sec Ehnström, Långström \& Hellqvist ... 109

Hirvenoja, M.: see Michailova \& Hirvenoja ................. 19

Hokkanen, H. T. M. \& Lipa, J.: Occurrence and dynamics of Nosema meligethi (Microsporida) in populations of Meligethes aeneus (Coleoptera, Nitidulidae) in Finland ................. 11

Huldén, L.: see Pekkarinen \& Huldén ........................... 57

Hynynen, J.: see Bagge \& Hynynen ............................ 99

Kallio, R.: see Sippola, Siitonen \& Kallio ................... 201

Karhu, K., Rassi, P. \& Rutanen, I.: Threatened insects of Ruissalo 123

Koponen, S. \& Niemelä, P.: Ground-living arthropods along pollution gradient in boreal pine forest ................... 127

Kullberg, J., Kuussaari, M. \& Nieminen, M.: Description of the female of Hyptioxestia magadanica, with notes on the occurrence of $H$. magadanica and $H$. penthima adults (Lepidoptera, Noctuidae) 197

Kuussaari, M.: see Kullberg, Kuussaari \& Nieminen ... 197

Lehikoinen, E.: see Veistola, Eeva \& Lehikoinen ....... 177

Lehtinen, P. \& Niemi, R.: The parthenogenetic mite Labidostomma luteum (Acarina Actinotrichida: Labidostommidae) in Finland 211

Linnavuori, R. E.: Hemiptera of Iraq. V. Lygaeidae ....... 29

Lipa, J.: see Hokkanen \& Lipa .................................... 11

Långström, B.: sce Ehnström, Långström \& Hellqvist . 109
Meeting participants (The XXIII Nordic Meeting of Entomology) 50

Meeting report (The XXIII Nordic Meeting of Entomology)

Michailova, P. \& Hirvenoja, M. Cytotaxonomic characteristics of Chironomus clarus (Diptera, Chironomidae) with completion of the description of morphology of adults and immature stages.

. 19

Muona, J.: Is Microrhagus lindbergi (Palm) (Coleoptera, Eucnemidae) a valid species? ..................................... 39

Niemelä, P.: see Koponen \& Niemelä .......................... 127

Niemi, R.: see Lehtinen \& Niemi .................................. 211

Nieminen, M.: see Kullberg, Kuussaari \& Nieminen .. 197

Nilsson, A. N.: Lectotype designation for Hydroporus septemvittatus Régimbart, 1883 (Coleoptera, Dytiscidae)

Nuorteva, P.: Transfer of cadmium from ants to ant-lions .. 133

Pekkarinen, A. \& Huldén, L.: Nature, particularly the insect fauna of Ladoga and Olonets Karelia ........................ 57

Pohtio, I. \& Teräs, I.: Bumblebee visits to different colour morphs of the Washington lupine, Lupinus polyphyllus

Polevoi, A. V.: see Zaitzev \& Polevoi ........................ 185

Proceedings of the XXIII Nordic Meeting of Entomology

Rassi, P.: see Karhu, Rassi \& Rutanen ....................... 123

Rutanen, I.: see Karhu, Rassi \& Rutanen ................. 123

Saaristo, M. I.: Distribution maps of the outdoor myrmicid ants (Hymenoptera, Formicidae) of Finland, with notes on their taxonomy and ecology .............................. 153

Siitonen, J.: see Sippola, Siitonen \& Kallio ............... 201

Silfverberg, H.: Immigration and range expansion in Finnish insects

163

Sippola, A.-L., Siitonen, J. \& Kallio, R.: Faunistics of Coleoptera in subarctic forests in Finnish Lapland .. 201

Sjöberg, K.: see Atlegrim \& Sjöberg ........................... 79

Ståhls, G.: Additions and deletions to Syrphidae (Diptera) of Finland

Talvi, T.: Carabid beetle assemblages (Coleoptera) in a wooded meadow and in the adjacent habitats on the Saaremaa Island, Estonia 169

Teräs, I.: see Pohtio \& Teräs ....................................... 139

Veistola, S., Eeva, T. \& Lehikoinen, E.: Seasonal occurrence of arthropods as a source of food for birds in Finnish Lapland 177 
Zaitzev, A. I. \& Polevoi, A. V.: New species of fungus gnats (Diptera, Mycetophilidae) from Kivach Nature Reserve, Russian Karelia 185

\section{Short reports (titles modified)}

Meinander, M.: Blaste quadrimaculata, a new species of Psocoptera to Finland I

Haarto, A.: New provincial records on six calliphorids and three sarcophagids (Diptera)

.. 1

Kangas, J.: New provincial record of Mycetoporus brucki (Coleoptera) .. 1

Martikainen, P.: New provincial record on Konowia betulae (Hymenoptera, Xiphyriidae) .. 2

Muona, J.: Six species of Coleoptera deleted from the fauna of Finland

.. 2

Rutanen, I.: New provincial records on Monotoma testacea and Ahasverus advena (Coleoptera)

I

- : One species of Coleoptera deleted from the fauna of
Finland 3

Silfverberg, H.: One species of Coleoptera deleted from the fauna of Finland

—: New records of Coleoptera from Estonia and Latvia 3

\section{Reviews}

Commonwealth Scientific Industrial Research Organization (ed.) 1994: Insects - A World of Diversity (Ulf Carlberg) .................................................................. 4 i

Heliövaara, K \& Väisänen, R. 1993: Insects and pollution (Seppo Koponen) 10

Kim, K. C. \& McPheron, B. A. 1993: Evolution of insect pests. Patterns of variation (Olli Halkka) 47

Notes

European Congress of Lepidopterology 196 